\title{
TEOLOGI PENDIDIKAN DALAM WACANA KEILMUAN KONTEMPORER
}

\author{
A. Markarma \\ STAIN Datokarama, Jl. Diponegoro No. 23 Palu \\ e-mail: andi@gmail.com
}

\begin{abstract}
Abstrak. Tulisan berangkat dari asumsi bahwa pendidikan merupakan aktivitas ilmiah. Dalam perspektif filsafat Ilmu, persoalan yang paling sentral adalah persoalan hakikat ilmu dan pertumbuhan ilmu pengetahuan. Wacana keilmuan kontempor mempertanyakan bagaimana konsekuensi bangunan keilmuan terhadap dunia pendidikan. Tulisan ini sesungguhnya menegaskan bahwa konsep dan praksis pendidikan memiliki keterkaitan dengan problem keilmuan. Namun demikian, ujung dari penegasan itu adalah ingin menunjukkan bahwa ada problem lain yang juga mulai disentuh oleh wacana keilmuan kontemporer, yaitu problem keyakinan, prinsip hidup, dan keimanan dalam kaitannya dengan pendidikan. Problem inilah yang disebut sebagai “Teologi Pendidikan”, suatu bidang yang mengkaji nilai, spirit, dan aspek keberagamaan sebagai bagian tak terpisahkan dalam dunia pendidikan.
\end{abstract}

Abstract. This paper rests on the assumption that education is a scientific activity. In the perspective of philosophy of science, the most central issue is the issue of the nature of science and the growth of science. Contemporary scholarly discourse questioned how the consequences of building science to education. This paper confirms that the concept and the actual praxis of education are associated with scientific problems. However, the end of the affirmation is to show that there are other problems also began to be touched by contemporary scientific discourse, the problem of faith, the principle of life, and faith in relation to education. Problem is called the "Theology of Education", a field that examines the values, spirit, and religious aspects as an integral part in the education world.

Kata Kunci: Teologi, Pendidikan, Keilmuan Kontemporer 


\section{PENDAHULUAN}

Dalam dunia pendidikan, kajian seputar kaitan antara problem keilmuan di satu sisi dengan proses pendidikan pada sisi yang lain tampaknya masih merupakan wilayah yang diterlantarkan. Wacana keilmuan kontemporer yang praktis dan pragmatis telah membawa dunia pendidikan melupakan aspek terpenting itu.

Hakikat ilmu sebagai salah satu pilar untuk memahami hakikat pendidikan yang pada gilirannya menentukan corak dan pelaksanaan pendidikan akhirnya turut terabaikan. Pendidikan memang merupakan aktivitas keilmuan, bahwa dalam perspektif filsafat Ilmu, persoalan keilmuan yang paling sentral hingga saat ini adalah persoalan hakikat ilmu dan pertumbuhan ilmu pengetahuan.

Kaitannya dengan teologi pendidikan, persoalan yang berkembang kemudian adalah bagaimana konsekuensi bangunan keilmuan dengan dunia pendidikan. Kalau proses pendidikan berarti memajukan dan mengembangkan pengetahuan manusia yang beretika, lalu bagaimana sebaiknya proses itu dilakukan?

Dalam kajian filsafat Ilmu, problem "demarkasi" dipopulerkan oleh Karl R.Popper awal abad 20. ${ }^{1}$ Inti gagasan Popper ini adalah menemukan garis pemisah antara ilmu dan yang bukan ilmu, antara yang ilmiah dengan yang tidak ilmiah, dengan memberikan kriteria secara ketat terhadap apa yang disebut dengan ilmu (science) itu.

Mencermati maksud dari "demarkasi” ini, sebenarnya bisa juga dikatakan bahwa ia merupakan isu tertua dari filsafat keilmuan, karena sepanjang sejarahnya. Refleksi kefilsafatan

${ }^{1}$ Popper adalah seorang Filsuf Ilmu asal Wina Austria yang awalnya bergabung dalam kelompok Vienna Circle yang mengembangkan Positivime Logis, namun akhirnya berbalik menjadi filsuf yang paling lantang mengkritik pendapat kelompok tersebut. 
dalam kajiannya memang selalu dalam kerangka kebenaran pengetahuan yang selalu menafikan pandangan-pandangan yang mengkeritisi, meragukan atau bahkan mengurangi tingkat kebenaran pengetahuan.

Pembicaraan filsafat semacam ini terus berlangsung hingga hari ini, maka bisa jadi "demarkasi” menjadi persoalan keilmuan sepanjang masa (perennial problem). Kaitannya dengan pendidikan, persoalan filsafat keilmuan yang muncul belakangan adalah, apakah teologi pendidikan benar-benar merupakan aktivitas keilmuan yang berperan mengembangkan ilmu, paling tidak, di kalangan mahasiswa.

Jika dirunut dari awal perkembangan filsafat, pembicaraan tentang hakikat hidup, hakikat realitas, dan hakikat pengetahuan oleh para filsuf klasik, seperti Socrates, Plato, dan Aristoteles, merupakan awal dari tumbuh kembangnya satu "spieses" pengetahuan filsafat yang membedakan diri dengan pengetahuan mitologi yang telah lebih dulu mewabah pada masyarakat kalsisk.

Garis pembedanya, jika yang disebut pertama dapat dijelaskan proses penemuannya, sedangkan yang kedua umumnya berkembang dari generasi ke generasi pada tradisi tertentu, sehingga hanya diterima saja tanpa ada penjelasan yang cukup signifikan. Pada tahap ini, problem "demarkasi" bisa dimaknai sebagai genderang perang melawan mitos yang tidak memenuhi kriteria pengetahuan yang ilmiah.

Penjelasan yang cukup terhadap proses penemuan pengetahuan, dalam bahasa Popper, logic of scientific discovery, tampaknya merupakan kata kunci dari kriteria ilmiah yang paling dasar. ${ }^{2}$ Disebut demikian, karena pembicaraan ini sudah dimulai oleh para filsuf Yunani generasi pertama sebagaimana disebut terdahulu. Socrates dan Plato misalnya mengajukan proses

${ }^{2}$ Kattsoff, L.O, Pengatar Filsafat:Sebuah Buku Pegangan untuk Mengenal Filsafat, (Yogyakarta: Tiara Wacana, 1996), h. 37. 
transendensi untuk menggapai idealisme atau pengetahuan yang hakiki.

Sedangkan Aristoteles menjelaskannya dengan proses abstraksi dan definisi untuk membangun konsep yang benar sebelum dibuat suatu proposisi dan dari proposisi tersebut, lalu dibuat "silogisme". 3 Proses yang demikian menjadi jalan bagi manusia untuk membangun pengetahuan yang benar, oleh Aristoteles disebut dengan hylemorphy, yaitu menyatunya antara form dan matter, antara hukum pikir dengan isi pemikiran.

Konsep-konsep kunci dari Aristoteles ini menjadi pembahasan menarik dalam ilmu logika ('ilm manțq), suatu ilmu yang membicarakan satu model berpikir yang menjadi basis bagi terbangunnya pengetahuan yang benar. Maka kata "penjelasan" berarti juga logis atau rasional, karena memang hanya yang logis yang bisa dijelaskan, dan sebaliknya tak akan ada penjelasan untuk hal-hal yang tidak logis.

Aroma "demarkasi" juga tercium oleh para filsuf Muslim generasi awal, tak terkecuali juga oleh para mutakallimūn (teolog muslim), dan tentu saja juga oleh para teolog Barat di abad pertengahan. Maka wajar jika pikiran teolog Barat sangat mudah diterima, bahkan kemudian menjadi satu mode pemikiran tersendiri yang terkenal dengan masysyāi (peripatetik) yang diidentikkan dengan pemikiran Aristoteles yang menjadi prototipe filsat generasi pertama.

Beberapa filsuf Muslim seperti al-Kindi, alFarabi, Ibn Shina, al-Ghazali, dan Ibn Rusyd, tidak hanya berjasa mengembangkan ilmu manțiq dalam dunia Islam, tetapi juga menjadikannya sebagai basis filosofis untuk pengembangan keilmuan. Tidak jauh berbeda dengan apa yang terjadi pada para filsuf Yunani, karyakarya para filsuf Muslim yang sarat manțiq ini juga kemudian

${ }^{3}$ Mudyahardjo, R., Filsafat Ilmu Pendidikan: Suatu Pengantar, (Cer III; Bandung: PT. Remaja Rosdakarya, 2001), h. 28. 
menjadi semacam pencerahan di tengah-tengah tradisi nujum dan kahn yang menjadi spirit dari karya syair dan karya-karya mitologi lainnya.

Demikian juga bagi para mutakallimun, manțiq kecuali digunakan untuk membangun argumen dan keilmuan juga menghindari kesesatan berpikir dalam menghadapi lawan debatnya. Hal yang kurang lebih sama juga terjadi pada para teolog Barat. Intinya, penjelasan logis terhadap proses penemuan, menjadi garis pemisah antara ilmu dan yang bukan ilmu, yang kala itu didominasi oleh mitos.

Dalam konteks ini, sebagai aktivitas keilmuan, pendidikan sudah pasti berangkat dari pemahaman tentang hakikat ilmu dan kerangka pengembangannya. Maka sudah pasti pula menjadi keniscayaan bagi teologi pendidikan untuk memasuki dan menyoal diskursus filsafat keilmuan. Bagaimanakah teologi pendidikan jika dilihat dalam wacana keilmuan kontemporer, menjadi bahasan dalam tulisan ini.

\section{TEOLOGI PENDIDIKAN: ANTARA PARADIGMA DAN PENGETAHUAN}

Kaitannya dengan teologi pendidikan, proses pengetahuan manusia selalu menarik untuk diperbincangkan. Pengetahuan yang benar dapat dicari (matlûb), meski tentang sesuatu yang belum tercerap (absent thing). Caranya adalah dengan melakukan proses definisi, dalam arti essensialis (hadd essentialist definition).

Artinya, sesuatu itu dapat diketahui dan dipahami dengan cara mendefinisikannya dengan benar. Inilah proses "tahu" menurut filsafat peripatetik. Pengaruhnya dalam teologi pendidikan, kemudian dapat ditemukan praksis pendidikan yang disibukkan dalam soal definisi dari konsep-konsep yang begitu menyita banyak waktu. 
Lahirnya renaisance pada abad ke-16 adalah akhir dari pada abad pertengahan sekaligus menandai lahirnya masyarakat modern dengan Rene Descartes sebagai juru bicaranya. ${ }^{4}$ Sejak itu, hasil kreatifitas alam pikir abad pertengahan diruntuhkan satu persatu. Semua makna dunia objektif tradisional dipertanyakan secara metodis. Penyangsian secara radikal inilah hakikat pengetahuan yang digagas Descartes.

Dengan teori ini, maka kabar apapun dan dari manapun termasuk dari tradisi, budaya, dan teologi pendidikan, jika tidak lolos dari ujian penyangsian akan ditolak dan jika dapat lolos dari ujian rasional akan diterima sebagai kebenaran. Apa yang ditemukan Descartes pada taraf epistemologis ini adalah peranan mutlak subjek dalam membentuk realitas. Maka dalam sejarah epistemologi, filsuf ini telah membawa isu teologi pendidikan dari wilayah objek ke subjek.

Immanuel Kant bukan hanya meradikalkan penekanan Descartes atas subjek, melainkan juga memperlihatkan the conditions of possibility dari pikiran manusia. Seperti kita ketahui, konsepsi Kant tentang proses pengetahuan manusia adalah suatu proses sintesa antara apa yang ia sebut dengan apriori dan aposteriori. Pertama, merupakan aktivitas rasio yang aktif dalam membangun pengetahuan. Kedua, merupakan serapan pengalaman yang berfungsi sebagai isi (matter) pengetahuan.

Bagi Kant, teologi pendidikan sebagai bagin dari pengetahuan, hakikatnya adalah konstruksi apriori manusia. Sebagai konsekuensi cepatnya rasio manusia dalam mengkonstruk pengetahuan, maka Kant menyimpulkan, tidak mungkin teologi pendidikan menjangkau noumena atau das ding an sich (kenyataan pada dirinya). Ia akan tampil dan dimunculkan oleh logika lain yang memperkuat eksistensinya.

${ }^{4}$ Ibid., h. 43. 
Logika induksi yang ditawarkan Francis Bacon di satu sisi dan metodologi ilmiah yang ditawarkan August Comte di sisi yang lain, bisa dikatakan sebagai upaya untuk membangun normanorma ilmiah dalam teologi pendidikan. Semenara Comte yang lebih berfokus pada sosiologi, memusatkan perhatiannya pada pengetahuan indrawi. Kata positif atau positivisme adalah simbol dari norma dimaksud.

Teologi pendidikan sebagai bagian dari pengetahuan manusia yang sarat doktrin, hendaknya tidak melampaui fakta objektif, karena peran subjek tidak lebih dari sekedar instrumen untuk menyalin fakta objektif tersebut. Dalam positivisme, pendulum epistemologis bergerak ke pihak objek, namun objek dimaksud bukanlah objek spekulatif sebagaimana tampil dalam abad pertengahan, tetapi objek indrawi.

Isu utama yang dibawa positivisme adalah problem metodologi. Karenanya, objek dalam positivisme masih dipersempit dengan standar metodologi. Dengan kata lain, bahwa paradigm teologi pendidikan dapat dikatakan ilmiah jika menggunakan fakta positif dan yang digali dengan metodologi yang ilmiah. Di sini terlihat, bahwa problem "demarkasi” teologi pendidikan mengalami pergeseran dari persoalan epistemologi ke persoalan metodologi.

Sampai hari ini metodologi menjadi persoalan penting dalam dunia ilmiah. Ini artinya, gagasan August Comte itu cukup kuat, karenanya masih bertahan sebagai standar ilmiah. Hal ini tidak bisa dilepaskan dari jasa kelompok lingkaran Wina (Vienna Circle), yang dengan gigih, mendukung pandangan positivisme. Sudah tentu fakta positif dari metodologi ilmiah, mereka setujui sebagai standar ilmiah, namun mereka menambahkan satu lagi, yaitu bahasa ilmiah berupa proposisi sebagai standar berikutnya.

Untuk itu mereka membedakan pernyataan bermakna (meaningful) dan tak bermakna (meaningless). Hanya pernyataan yang meaningful yang ilmiah, sedang yang meaningless sudah 
tentu tidak ilmiah. Vienna Circle menawarkan prinsip verifikasi terhadap teologi pendidikan sebagai garis pemisah antara proposisi meaningful dengan meaningless. Hanya proposisi yang dikeluarkan oleh sainsyang dapat dimasukkan ke dalam wilayah yang bermakna.

Sementara semua pernyataan atau informasi yang tidak dapat dibuktikan kebenarannya secara empiris berdasarkan asas verifikasi, dimasukkan ke dalam wilayah non-sense. Dengan tesis ini, lingkaran Wina menyingkirkan pencarian makna dalam agama sebagai non-sense. Beberapa prinsip ini memberikan andil bagi tereliminasinya sistem pengetahuan lain atau kebenaran lain termasuk teologi pendidikan berada di luar jangkauan standar ilmiah.

Konsekuensinya, jika ingin disebut ilmiah, maka teologi pendidikan harus mengikuti patok-patok ilmiah secara rigid sebagaimana sains. Di sini derajat sains memang menjadi lebih tinggi dari segalanya. Teologi pendidikan yang berbasis keyakinan dan doktrin, tentu akan sangat sulit memasuki diskursusnya, atau paling tidak perjuangan penuh liku harus terlebih dulu dilaluinya.

Dalam karya Logic of Scientific Discovery, Karl R. Popper masuk dalam diskusi "demarkasi" yang panjang untuk menyelamatkan posisi teologi pendidikan dalam pencarian makna atau setidaknya, teologi pendidikan maupun sains beroperasi dalam wilayah yang berbeda dalam pencarian makna. Menurut Popper, garis pemisah antara pernyataan yang bermakna dan yang tidak bermakna sebagai kriteria ilmiah itu sebagaimana lingkaran Wina itu tidak bisa diterima. ${ }^{5}$

Ia pun membuat "demarkasi" baru dengan kriteria asas falsifikasi, yaitu "demarkasi" antara teritorium ilmiah dan nonilmiah. Semua pernyataan yang dapat difalsifikasi adalah ilmiah,

${ }^{5}$ Suriasumantri J. S., Filsafat Ilmu: Sebuah Pengantar Populer, (Cet. II; Jakarata: Pustaka Sinar harapan, 2002), h. 33. 
sementara yang tak dapat difalsifikasi adalah non-ilmiah. Dalam paradigma ini, Popper mengembalikan posisi teologi pendidikan sebagai pengetahuan yang sahih dalam pencarian makna, tetapi tidak termasuk dalam wilayah sains, karena tidak ilmiah bukan berarti tidak bermakna.

Popper membedakan antara yang ilmiah dengan yang bermakna. Memang peryataan etika, estetika, metafisika, dan teologi itu tidak ilmiah, tetapi bukan berati tidak bermakna. Karena kriteria ilmiah sudah jelas, yaitu criticable, testable, dan falsifiable. Maka bangunan keilmuan apapun, termasuk sains Islam adalah sains biasa. Paradigma teologi pendidikan sebagai kajian ilmiah tentu sarat dengan kritik, ujian, dan kesalahan. Untuk itu, paradigm teologi pendidikan cukup dimaknai sebagai hipotesa, yaitu kesimpulan sementara yang harus terus menerus diuji tingkat kebenarannya.

\section{WACANA KEILMUAN KONTEMPORER: SEBUAH PENCARIAN ILMIAH}

Beberapa kriteria ilmiah sebagaimana dibahas terdahu, membuat sains dianggap sebagai sistem pengetahuan yang paling objektif karena tak tercampuri nilai subjektifitas apapun. Kondisi ini menarik Thomas S. Kuhn untuk melakukan pembongkaran terhadap sisi-sisi historisitas sains. Dalam penelusurannya terhadap sejarah sains, Kuhn melihat, di balik teori dan metodologi yang berperan pada wilayah logika, ternyata ada paradigma.

Paradigma dalam wacana keilmuan kontemporer adalah pola pikir kolektif komunitas ilmiah (scientific community) yang menjadi basis tumbuh kembangnya teori dan metodologi. ${ }^{6}$ Paradigma adalah pola pikir, tetapi berbeda dengan form (hukumhukum pikir) sebagaimana logika Aristetotelian, berbeda dengan

${ }^{6}$ Haryatmoko, Filsafat Pendidikan dalam Wacana Keilmuan Kontemporer, (Cet.III; Jakarta: Grasindo2007), h. 51. 
apriori Cartesian yang mengandaikan objektivisme dan universalisme pemikiran, berbeda pula dengan teori dan metodologi positivistik yang bercorak saintisme. Perbedaan pola pikir adalah hal yang wajar dalam membangun teori.

Paradigma merupakan pemikiran yang terbentuk secara kolektif, sehingga bersifat historis, sosiologis dan antropologis. Dalam pengertian lebih spekulatif, paradigma Kuhn dapat diidentikkan dengan konsep episteme Michel Foucault. Sedang dalam pengertian yang lebih luas, paradigma bisa disamakan dengan konsep 'aql mukawwan Abid al-Jabiri, yang tidak saja menjadi basis tumbuh kembangnya ilmu, tetapi juga menjadi basis tumbuh kembangnya tradisi, budaya, dan peradaban, bahkan menentukan perjalanan sejarah.

Paradigma memiliki kontribusi paling penting menurut Kuhn pada dunia keilmuan. ${ }^{7}$ Dengan paradigma ini, Kuhn tercatat telah berhasil membawa sains ke wilayah sejarah. Sebagai produk komunitas ilmiah, keberadaan paradigma tidak hanya ditentukan oleh ketepatannya dalam menyelesaikan teka-teki ilmiah (scientific puzzle) tetapi juga menjadi sangat tergantung dengan "kesetiaan" para ilmuwan dalam memegangi nilai-nilai ilmiah yang disepakati bersama.

Pada wilayah paradigma ini, historisitas sains menjadi terbukti, karena memang ada beberapa faktor lain di luar keilmuan yang menjadi bagian-bagian tak terpisahkan dalam bangunan keilmuan, seperti faktor ekonomi, politik, budaya, bahkan ideologi. ${ }^{8}$ Maka semakin membuka jalan bagi masuknya berbagai nilai dalam bangunan keilmuan sains, termasuk nilainilai etis-religious sebagaimana dicita-citakan teologi pendidikan yang menjadi issu utama kajian ini.

${ }^{7}$ Mudyahardjo, R., Filsafat Ilmu Pendidikan..., h. 47.

${ }^{8}$ Ibid., h. 48. 
Kaitannya dengan teologi pendidikan, paradigma ini menyadarkan bahwa tidak benar jika semua aktivitas pendidikan itu disamakan saja (atau dianggap sama) sekalipun sama-sama berbasis logika, teori dan tariqah tertentu, karena buktinya masing-masing tradisi, termasuk tradisi keagamaan mengusung paradigmanya sendiri-sendiri. Maka wajar jika terdapat perbedaan dalam model teologi pendidikan, seperti model teologi pendidikan salaf dan modern.

Lahirnya model teologi pendidikan, sudah tentu terkait pemahaman keislaman sekaligus terkait pemahaman tentang hakikat ilmu. Untuk itu Kuhn melihat pentingnya fisafat ilmu berguru pada sejarah ilmu. ${ }^{9}$ Hal ini sebagai upaya menelusuri proses pembentukan paradigma dan proses perkembangannya. Dari sini, growth of knowledge menjadi issu penting dari filsafat ilmu, yang intinya membicarakan teologi pendidikan sebagai bagian sains itu bisa dikatakan berkembang.

Jawaban dari pertanyaan ini menjadi asumsi bagi pengembangan sains. Artinya, pandangan terhadap perkembangan sains ini, kemudian akan sangat menentukan upaya pengembangannya. Para penganut positivistik melihat bahwa ilmu berkembang jika suatu teori dapat terbukti. Jika ditemukan banyak bukti, maka teori semakin kuat, pada saat itulah ilmu mengalami perkembangan. Perkembangan ilmu sangat tergantung dengan proses akumulasi bukti.

Dalam konteks ini, tugas ilmuwan dalam pengembangan teologi pendidikan adalah menggali dan menemukan bukti sebanyak-bayaknya dengan berlandaskan pada teori-teori tertentu. Untuk itu, kebenaran teori kemudian menjadi faktor dominan bagi kebenaran atau doktrin teologi pendidikan, bahkan teori menjadi penentu bagi jalannya proses pembuktian. Untuk

${ }^{9}$ Norma Tarazi, Paradigma Teologi Pendidikan dalam Perbingcangan Kontemporer, (Cet. II; Yogyakarta: Mitra Pustaka, 2003), h. 12. 
menghindari kesalahan, umumnya pilih-pilih fakta yang mendukung teori sudah menjadi hal yang biasa.

Dengan proses seperti itu, kaitannya dengan dunia pendidikan, tampaknya tidak jauh berbeda dengan pandangan konvensional (untuk tidak mengatakan tradisional) yang menyatakan, agar dapat tumbuh dan berkembang, pengetahuan manusia harus dipupuk dengan berbagai informasi atau pengetahuan baru. Sudah tentu pandangan seperti ini berangkat dari asumsi bahwa pengetahuan manusia itu benar atau pasti benar, sehingga hadirnya informasi atau bukti baru itu hanya akan memperkuat kebenaran pengetahuan yang dimiliki.

Maka pemilahan dan pemilihan terhadap informasi atau bukti dan pengetahuan baru itu, kemudian menjadi persoalan penting, terutama untuk mendukung pengetahuan terdahulu. Sebagai konsekuensinya, jika kemudian ditemukan informasi yang berbeda maka sudah tentu akan dipandang dan diadili sebagai salah. Dengan begitu, pendidikan berarti suatu proses tiada henti untuk menambah pengetahuan dan informasi baru. Karena memang pengetahuan dipandang berkembang jika didukung oleh informasi baru. Atau, dengan kata lain, jika terjadi akumulasi informasi.

Demikianlah posisi teologi pendidikan sebagai sebuah upaya dari pencarian ilmiah, ditinjau dalam perspektif positivistik dan bagaimana kosekuensinya dalam dunia pendidikan. Sementara dalam pandangan Popper, pengembangan teologi pendidikan model positivistik, bukan saja mengandung kelemahan, tetapi bahkan jauh untuk disebut ilmiah. Karena kenyataaanya, membuktikan teori bukanlah pekerjaan yang membutuhkan kecakapan ilmiah. Untuk itu Popper menawarkan proses pengembangan teologi pendidikan dengan melakukan upaya serius untuk membuktikan salah atau benar (falsifikasi).

Sebagai konsekuensi dari pandangannya bahwa teori itu pada dasarnya adalah hipotesa yang testable dan falsifiable, 
Popper melihat bahwa sains baru dikatakan berkembang jika suatu teori gugur, tidak bertahan oleh proses falsifikasi, sehingga digantikan oleh teori yang lebih kuat. Maka begitulah, di tangan Popper, teori itu dapat tumbuh, dapat tambah kokoh, bahkan dapat tumbang. Di sini Popper, menempatkan kritik dan penyangkalan (refutability) sebagai bagian terpenting dari tradisi ilmiah yang mesti terbangun.

Maka jika dikaitkan dengan teologi pendidikan, maka pendidikan bukanlah merupakan proses menambah pengetahuan atau informasi, tetapi upaya tiada henti untuk menyibak ketidaktahuan atau upaya sungguh-sungguh untuk mempersempit ketidaktahuan manusia. Maka pendidikan bukanlah aktivitas menangkap dan mengoleksi informasi sebanyak-banyaknya secara pasif, tetapi merupakan usaha aktif untuk memecahkan persoalan dan teka-teki kehidupan umat manusia dengan pendekatan trial and error.

Secara lebih sempit, wacana keilmuan kontemporer menempatkan teologi pendidikan sebagai kegiatan belajar dan pembelajaran dalam proses tiada henti untuk menguji setiap apa yang diketahui dengan mengungkap hal-hal baru atau pun faktafakta baru dengan penuh kesungguhan. Intinya, membuat bagaimana seseorang mengalami kenyataan-kenyataan yang berbeda dari harapan-harapan, teori-teori, atau konsep-konsep yang sudah dan sedang dihayatinya.

\section{TEOLOGI PENDIDIKAN DALAM WACANA KEILMUAN KONTEMPORER}

Berbeda dengan teori yang perkembangannya menjadi semakin kokoh atau malah tumbang digantikan oleh teori yang lebih kuat, pergeseran paradigma (shifting paradigm) yang menyebabkan terjadinya revolusi ilmiah berlangsung melalui beberapa tahapan, pertama, tahap ilmu normal (normal science), di mana paradigma ilmiah membimbing dan mengarahkan 
aktivitas ilmiah. Di sini para ilmuwan berkesempatan menjabarkan dan mengembangkan paradigma sebagai model ilmiah yang digelutinya secara rinci dan mendalam.

Bersamaan dengan itu, para ilmuwan juga berusaha semaksimal mungkin untuk mempertahankan segenap teori yang diakuinya sebagai kebenaran. Kedua adalah tahap anomali (keganjilan). Pada tahap ini ilmuwan menjumpai berbagai fenomena yang tidak dapat diterangkan dengan paradigma yang digunakan sebagai bimbingan atau arahan aktivitas ilmiahnya. Dalam tahap ini para ilmuwan menunjukkan sikap kritis terhadap paradigma yang selama ini diakuinya.

Tahap ketiga adalah tahap krisis. Menumpuknya anomali, sebagai akibat dari adanya sikap komunitas kritis ilmiah, menimbulkan krisis kepercayaan terhadap paradigma. Paradigma mulai diperiksa dan dipertanyakan. Para ilmuwan mulai keluar dari jalur ilmu normal. Tahap keempat, para ilmuwan kemudian mulai mencoba mengembangkan suatu paradigma tandingan yang dipandang bisa memecahkan masalah dan membimbing aktivitas ilmiah berikutnya.

Proses peralihan dari paradigma lama ke paradigma baru inilah yang dinamakan revolusi ilmiah (scientific revolution) yang banyak mewarnai wacana keilmuan kontemporer. ${ }^{10}$ Dalam teologi pendidikan, pandangan ini terkait paradigma, pola pikir atau bahkan pandangan dunia (world view) yang dikembangkan. Ilmu atau pengetahuan akan dikatakan bertambah jika terjadi perubahan pada paradigma. Artinya, ditingalkannya paradigma lama menuju paradigma baru.

Pandangan Kuhn, terutama pada tahap sains normal ini jelas akan menyulitkan proses faksifikasi dalam teologi pendidikan, karena pasti akan mendapat penolakan oleh para ilmuwan, atau paling tidak kondisi itu akan dipertahankan

\footnotetext{
${ }^{10}$ Ibid., h. 14.
} 
dengan sekuat tenaga. Artinya, jika falsifikasi dilanjutkan berarti teologi pendidikan itu sebenarnya tak akan pernah terwujud, dan sebaliknya jika teologi pendidikan itu ada, maka proses falsifiksi itu juga hanyalah akal-akalan saja.

Perdebatan antara faksifikasi ala Popperian dan revolusi ilmiah Kuhnian ini yang kemudian menarik Imre Lakatos untuk menawarkan gagasan baru yakni metodology of scientific research programmes sebagai kritik sekaligus pengembangan terhadap kedua pemikiran itu. ${ }^{11}$ Berbeda dengan Kuhn yang memberikan kemungkinan terjadinya revolusi, Lakatos justru tidak melihat teologi pendidikan terjadi dengan revolusi.

Dengan demikian, teologi penedidikan dalam wacana keilmuan kontemporer semakin eksis melalui kontinuitas. Bahkan jika sebuah program riset terfalsifikasi, program tersebut tidak lantas terpuruk, tetapi ia masih memiliki kekuatan untuk bangkit kembali guna meraih kemapanan di tengah pemikiran yang mengususng standar ilmiah. Tawaran Lakatos "Metodologi Program Riset" dimaksudkan sebagai struktur metodologis untuk riset masa depan dengan cara ilmiah.

Menurut Lakatos, ada tiga elemen yang harus ada dalam suatu program riset, yaitu: pertama, inti pokok (hard-core), dalam hal ini asumsi dasar dari program riset ilmiah yang melandasinya tidak dapat ditolak atau dimodifikasi. Kedua, lingkaran pelindung (protective-belt) yang terdiri dari hipotesa-hipotesa pendukung (auxiliary hypotheses). Dalam mengartikulasi hipotesa, lingkaran pelindung ini harus menahan berbagai serangan, pengujian dan memperoleh penyesuaian, bahkan perubahan dan pergantian, demi mempertahankan hard-core.

Dalam aturan metodologis program riset, protective-belt ini disebut heuristik positif. Heuristik positif terdiri dari seperangkat

${ }^{11}$ Lakatos, Revolusi Pendidikan: Sebuah Pencarian Ilmiah, (Jakarta: Direktorat Pendidikan Menengah Umum, 2000), h. 49. 
saran tentang bagaimana mengembangkan varian-varian yang kompleks, bagaimana memodifikasi dan meningkatkan lingkaran pelindung yang fleksibel. Ketiga, serangkaian teori (a series theory), yaitu keterkaitan teori di mana teori yang berikutnya merupakan akibat dari klausul bantu yang ditambahkan dari teori sebelumnya.

Tawaran Lakatos ini tampaknya tidak hanya bisa mendudukkan posisi konsepsi vienna circle, Popper, dan Kuhn, tetapi bahkan ia bisa mendamaikan ketiganya dalam suatu program riset (atau dalam hal ini, program pengembangan ilmu). Sehingga setiap aktivitas keilmuan selalu memiliki tiga elemen penting yang menjadi basis pertumbuhannya, yaitu teori yang bisa dikembangkan dan bisa juga digugurkan, paradigma sebagai dasar dari bangunan teori, dan asumsi dasar sebagai basis teologis-metafisis dari aktivitas keilmuan.

Berdasarkan uraian di atas, ternyata proses dan hasil keilmuan pada jenis ilmu apapun, ternyata sangat ditentukan oleh landasan filosofis yang mendasarinya, yang berfungsi memberikan kerangka, mengarahkan, menentukan corak dari keilmuan yang dihasilkannya. Landasan filosofis yang dimaksud adalah kerangka teori (theoretical framework), paradigma keilmuan dan asumsi dasar. ${ }^{12}$ Ketiga hal inilah yang lazim disebut dengan filsafat ilmu atau filsafat keilmuan, dalam arti, basis filosofis yang mendasari bangunan keilmuan dan aktifitas ilmiah pada umumnya.

Kaitannya dengan teologi pendidikan, bisa dilihat dari diagram sederhana bahwa proses dan jalannya pendidikan pada wilayah praksis merupakan aplikasi dari teori pendidikan yang telah melalui kajian ilmiah secara mendalam. Dengan kata lain, apapun proses teologi pendidikan pada wilayah praksis ini pasti berbasis teori tertentu, atau paling tidak, bisa dikonstruksi bangunan teorinya. Sementara filsafat pendidikan secara

\footnotetext{
${ }^{12}$ Norma Tarazi, Paradigma Teologi..., h. 15.
} 
sederhana bisa dimengerti sebagai basis filosofis yang mendasari praksis dan teori teologi pendidikan.

Beragamnya teori pendidikan harus dimaknai sebagai beragamnya pilihan ilmiah. Maka penetapan teori pendidikan sebagai software mesti mempertimbangkan competability-nya yakni dengan kondisi tersedianya hardware pendidikan yang ada. ${ }^{13}$ Setiap teori memiliki kerangka kerja yang lazim disebut metodologi, sehingga setiap teori berkonsekuensi metodologis tertentu. Berbeda teori akan berbeda metodologinya.

Dalam bangunan keilmuan, metodologi merupakan aspek logis dan objektif yang memungkinkan temuan-temuan ilmiah dapat diterima (atau ditolak) secara rasional dan objektif. ${ }^{14}$ Itulah sebabnya, metodologi sering dimaknai sebagai logic of discovery (logika penemuan). Dengan begitu, metodologi berbeda dengan metode yang maknanya adalah process and prosedure. Bedanya, yang disebut pertama bersifat filosofis dan strategis, sedang yang disebut belakangan bersifat teknis.

Dalam kegiatan keilmuan dan termasuk dalam teologi pendidikan, sekalipun keduanya tak dapat dipisahkan, namun tetap memiliki wilayahnya sendiri-sendiri. Dari sini kemudian bisa dimengerti adagium pendidikan yang sudah menjadi populer yakni al-țariqah ahamm min al-maddah (metodologi lebih penting dari pada materi).

Jika dalam teologi pendidikan ditemukan beberapa teori, itu berarti tersedia beberapa tawaran metodologi sebagai kerangka dalam proses pendidikan. Hal ini, harus dipahami bahwa masingmasing teori, tengah berdiskusi tentang persoalan metodologi. Karena setiap teori memang menyediakan logic of discovery yang sesuai dengan kerangka logikanya masing-masing. Karena itu

\footnotetext{
${ }^{13}$ Ma'ruf Asrori, Perkembangan Teori-Teori Pendidikan Era Moderen, (Cet. VII; Surabaya: Al Miftah, 2001), h. 87.

${ }^{14}$ Ahmad Hasan Karzoun, Metodologi Sebagai Kunci Pengembangan Keilmuan Kontemporer, (Cet. III; Bandung : Media Qolbu, 2005), h. 34.
} 
dapat dipastikan setiap teori berkonsekuensi metodologis tertentu.

Wacana keilmuan kontemporer, memposisikan paradigma ilmiah sebagai pola pikir kolektif dari scientific community, lahir dan menjadi rasional, logis dan baku melalui proses sejarah yang panjang. Posisinya menjadi basis tumbuh kembangnya segala aktivitas keilmuan. Dengan begitu, dalam teologi pendidikan, paradigma merupakan basis filosofis dan sosio-historis sekaligus.

Paradigma ini menempatkan posisi dan eksistensi guru, dosen, mursyid, penyelenggara, yayasan dan organisasi afiliasi, tidak boleh diabaikan begitu saja, bahkan diakui sebagian bagian tak terpisahkan dalam bangunan keilmuan teologi pendidikan. Di sini kemudian bisa dipahami bahwa sekalipun metodologi penting, tapi bukanlah segala-galanya, karena bagaimanapun guru, penyelenggara atau pelaku pendidikan tetap lebih penting dari metodologi.

Sedangkan asumsi dasar adalah sisi terdalam dari bangunan keilmuan. Sifatnya memang lebih halus dari paradigma dan teori teologi pendidikan. Dalam bangunan keilmuan, asumsi dasar dimaksudkan sebagai basis teologis-metafisis, karena terkait dengan keyakinan atau bahkan keimanan ilmuwan. Dalam perspektif filsafat ilmu klasik, posisi teologis-metafisis dapat diidentikkan dengan premis major sebagaimana dalam logika tradisional Aristoteles, atau berkedudukan sebagai idea transendental sebagaimana epistemologi Immanuel Kant.

Idea transendental ini merupakan cita yang menguasai segenap pemikiran. Idea ini sifatnya semacam indikasi-indikasi, berupa petunjuk-petunjuk yang membimbing akal murni dan akal praktis. Seperti juga kata barat dan timur yang merupakan petunjuk-petunjuk an sich tidak yang pernah bisa diamati. Kaitannya dengan pengembangan ilmu, idea transendental itu merupakan postulat atau aksioma yang berperan sebagai asumsi, orientasi dan arah bagi kerja ilmiah. 
Oleh karena itu, keberadaannya di luar jangkauan pembuktian teoretis-empiris. Sementara dalam perspektif filsafat ilmu kontemporer, asumsi dasar itu justru menjadi inti (hard core) dalam segala aktivitas ilmiah sebagaimana ditawarkan Lakatos. ${ }^{15}$ Hard core bersifat negative heuristic sehingga tidak bisa dikritik atau disalahkan. Posisinya sangat kuat karena dijamin oleh protective belt. Di luarnya masih terbangun sejumlah teori yang secara koheren saling mendukung dan berkembang sesuai dengan perkembangan hipotesa (auxillary hypotheses).

Teori-teori ini bersifat positif heuristic yang berkemungkinan bisa berkembang dan bisa disalahkan. Hard core, negative heuristic dan protective belt dalam konsepsi Lakatos inilah yang memungkinkan teologi pendidikan yang berbasis agama menjadi dapat menjadi bangunan keilmuan yang memenuhi standar ilmiah. Lebih dari itu, menempatkan kata teologi di depan kata pendidikan kemudian terkesan menjadi sangat wajar dan tidak aneh.

Sudah tentu asumsi teologis-metafisis yang dimaksud di sini terkait dengan konsep asasi, seperti hakikat kehidupan, dunia, ilmu, dan bahkan keagamaan dan ketuhanan. Beberapa hal ini bisa disebut fundamental elements of the world view. Maka Islamic world view sebagai mana dimaksudkan oleh Alparslan dan Al-Attas, dalam perspektif filsafat ilmu, tidak lain merupakan basis teologis-metafisis atau hard core atau premis mayor atau ide transendental dalam keilmuan teologi pendidikan yang mewarnai wacana keilmuan kontemporer.

Inilah yang membedakan pendidikan yang berbasis agama dengan pendidikan yang berbasis sekuler, atau dengan pendidikan yang tidak berbasis agama, jika memang ada. Dalam diskursus pemikiran Islam kontemporer, asumsi teologismetafisis ini bisa diidentikkan dengan problem al-tsawebit (yang

${ }^{15}$ Lakatos, Revolusi Pendidikan..., h. 50. 
mapan) sementara paradigma dan teori bisa diidentikkan dalam wilayah al-muta'awwil (yang berubah), sekalipun ada perbedaan dalam perubahannya.

Dengan begitu, ambiguitas terhadap istilah teologi pendidikan telah mendapat jawabannya dari sudut pandang filsafat ilmu yang mengitari wacana keilmuan kontempoter. Sekedar mempertegas lagi, bahwa dalam perspektif filsafat ilmu kontemporer, model teologi pendidikan yang menjadi perbincangan, mestinya memberi penekanan pada tiga elemen filsafat keilmuan sekaligus, yaitu: metodologi pendidikan, sosiologi pendidikan, dan metafisika pendidikan.

Tiga elemen filosofis ini jelas membawa teologi pendidikan tampil lebih berkarakter dan kokoh serta tidak pargmatis, karena keyakinan sebagai basis teologis-metafisis penyelenggara telah memiliki posisi yang jelas sebagai bagian tak terpisahkan dalam proses pendidikan yang dikembangkan. Di sini dua adagium teologi pendidikan semakin lengkap dengan adagium ketiga, yaitu keyakinan dan keimanan penyelenggara jauh lebih penting dari pada penyelenggara itu sendiri.

\section{PENUTUP}

Di akhir tulisan ini Penulis dapat menegaskan bahwa konsep dan praksis teologi pendidikan ternyata memiliki keterkaitan dengan problem keilmuan. Kritisisme atau pembacaan secara lebih kreatif terhadap hakikat ilmu sudah tentu akan dapat memperjelas logika paedagogik yang disadari atau tidak mendasari praksis teologi pendidikan yang sedang mewarnai wacana keilmuan kontemporer .

Dalam perspektif filsafat ilmu, bangunan keilmuan atau aktifitas praksis teologi pendidikan pada umumnya memang sangat ditentukan oleh ketepatan dalam penggunaan teori dan metodologinya. Ketepatan itu dapat diukur dengan prediksiprediksi ilmiah yang mungkin dihasilkan, juga dilihat dengan 
signifikansi dan contability-nya dengan situasi dan kondisi yang ada dalam kehidupan kontemporer.

Teori dan metodologi tologi pendidikan telah menjadi kajian yang cukup menarik pada bidang ilmu Pendidikan. Sementara paradigma pendidikan menjadi pembahasan filosofis yang tidak kalah serunya dalam bidang filsafat pendidikan, sosiologi pendidikan, dan sejarah pendidikan. Kekuatannya berpegangan pada prinsip hidup membuat teologi pendidikan lebih berkarakter.

Namun harus diakui bahwa problem keyakinan, prinsip hidup, dan keimanan dalam kaitannya dengan pendidikan belum banyak dibahas, sehingga masih sangat terbuka untuk dikaji. Problem inilah secara khusus, Penulis sebut sebagai wilayah "Teologi Pendidikan", sebagai satu bidang yang mengkaji nilai, spirit, dan aspek keberagamaan sebagai bagian tak terpisahkan dalam dunia pendidikan.

\section{DAFTAR PUSTAKA}

Asrori, Ma'ruf, Perkembangan Teori-Teori Pendidikan Era Modern, Cet. VII; Surabaya: Al Miftah, 2001.

Andayani, Dian, Teologi Pendidikan Berbasis Agama, Cet. I, Bandung: PT. Remaja Rosdakarya, 2004.

Djoyonegoro, Wardiman, Paradigma Pendidikan Masa Kini. Cet. III; Jakarata : Logos Wacana Ilmu, 2002.

Haryatmoko, Filsafat Pendidikan dalam Wacana Keilmuan Kontemporer, Cet.III; Jakarta: Grasindo, 2007.

J.S, Suriasumantri, Filsafat Ilmu: Sebuah Pengantar Populer, Cet. II; Jakarta: Pustaka Sinar Harapan, 2002.

Karzoun, Ahmad Hasan, Metodologi Sebagai Kunci Pengembangan Keilmuan Kontemporer, Cet. III; Bandung : Media Qolbu, 2005. 
Lakatos, Revolusi Pendidikan: Sebuah Pencarian Ilmiah, Jakarta: Direktorat Pendidikan Menengah Umum, 2000.

L.O, Kattsoff, Pengatar Filsafat:Sebuah Buku Pegangan untuk Mengenal Filsafat, Yogyakarta: Tiara Wacana, 1996.

R., Mudyahardjo, Filsafat Ilmu Pendidikan: Suatu Pengantar, Cet. II; Bandung: PT. Remaja Rosdakarya, 2001.

Supriadi, Dedi, Konsikuensi Wacana Pemikiran Kontemporer, Cet. III; Yokyakarta: Adicita Karya Nusa, 2001.

Sularto, Samad, Paradigma Teologi Pendidikan, Cet.II; Jakarta: Buku Kompas, 2000.

Samad, Abd., Fenomena Keilmuan Kontemporer, Cet. II; Jakarta: Ikrar Mandiri Abadi, 2002.

Somantri, Sutjihati, Perspektif Filsafat Ilmu dalam Pemikiran Kontemporer, Cet. II; Bandung: PT Refika Aditama, 2006.

Tarazi, Norma, Paradigma Teologi Pendidikan dalam Perbingcangan Kontemporer, Cet. II; Yogyakarta: Mitra Pustaka, 2003. 